\title{
KESUNYIAN DALAM KALANGAN WARGA EMAS: PRAKTIK SEMASA DAN SOLUSI DARI RISALAH AN-NUR
}

\author{
Noornajihan Jaafar, Rezki Perdani Sawai, Shah Rizul Izyan, Celal \\ Akar \\ Universiti Sains Islam Malaysia \\ noornajihan@usim.edu.my
}

\begin{abstract}
Abstrak
Sebagai manusia biasa, kita tidak terlepas dari berasa sunyi. Walaupun setiap individu akan mengalami kesunyian pada suatu ketika dalam kehidupan mereka, kebanyakkan kajian menekankan bahawa warga emas sangat terdedah kepada risiko untuk mengalami kesunyian. Kesunyian sekiranya tidak dicegah dan dirawat boleh membawa kepada penurunan daya tahan kepada jangkitan, kemerosotan kognitif dan membawa kepada masalah kesihatan mental seperti kegelisahan dan kemurungan. Artikel ini akan membincangkan definisi kesunyian, teori kesunyian, praktik semasa dan juga pendekatan mengatasi kesunyian menurut Risalah An-Nur bagi golongan warga emas. Metodologi yang digunakan dalam kajian ini ialah kajian kualitatif dengan menggunakan sumber-sumber bertulis khususnya kitab Risalah An-Nur sebagai bahan pengumpulan data. Kajian mendapati beberapa teori kesunyian telah diketengahkan oleh penyelidik seperti teori eksistential, teori psikodinamik, teori kognitif, teori interaktiosis, teori intelek dan teori sosial. Solusi dari perspektif Risah An-Nur mendatangkan tiga harapan sebagai penawar kepada kesunyian dalam kalangan warga emas. Selain itu turut dibincangkan solusi dari perspektif psikososial dan daya tindak dalam mengatasi kesunyiaan dalam kalangan warga emas. Beberapa solusi praktikal yang dibincangkan dalam penulisan ini diharapkan sedikit sebanyak berupaya menjadi panduan kepada warga emas secara langsung dan kepada pengusaha pusat penjagaan waga emas serta pihak kerajaan secara tidak langsung dalam menjaga kebajikan kelompok warga emas di Malaysia.

Katakunci: Kesunyian, Warga Emas, Risalah An-Nur
\end{abstract}




\section{Kesunyian Dalam Kalangan Warga Emas: Praktik Semasa Dan Solusi Dari Risalah An-Nur}

\section{Pendahuluan}

Populasi penduduk di Malaysia menunjukkan kecenderungan peningkatan populasi warga emas. Pertubuhan Kesihatan Sedunia, (2013) mendifinisikan warga emas sebagai mereka yang berusia 65 tahun dan lebih tua berdasarkan kronologi definisi umur. Manakala, di Malaysia, warga emas merujuk kepada mereka yang berumur 60 tahun ke atas dengan mengambil kira definisi yang ditetapkan oleh Pertubuhan Bangsa-Bangsa Bersatu (Dasar Warga Emas Negara).

Pertumbuhan urbanisasi dalam kalangan penduduk yang lebih muda dan perubahan sistem keluarga di Malaysia telah menyebabkan kesan yang besar terhadap penjagaan warga emas, termasuk penempatan semula rumah kebajikan warga emas. Jabatan Kebajikan Masyarakat Malaysia telah mengambil inisiatif untuk menyediakan kemudahan penjagaan warga emas dengan menyediakan rumah kediaman yang dikenali sebagai Rumah Seri Kenangan. Kemudahan yang disediakan termasuklah rawatan, dan pemulihan bagi meningkatkan kualiti hidup warga emas yang kurang berkemampuan. Terdapat pelbagai aktiviti yang dirancang bagi penghuni rumah tersebut. Antaranya merangkumi senaman (setiap pagi), bermain permainan atau karaoke dan bermain alat muzik tradisional. Penghuni boleh memutuskan sama ada mereka mahu mengambil bahagian atau tidak dalam aktiviti yang dijadualkan.

Rumah kebajikan warga emas swasta juga mempunyai aktiviti berjadual yang serupa dengan aktiviti di rumah kebajikan awam seperti bersenam dan bermain permainan. Sementara itu, aktiviti kerohanian seperti solat berjemaah dan belajar mengenai agama juga disediakan. Walau bagaimanapun, kajian literatur menunjukkan bukti kadar kesunyian meningkat dalam kalangan orang yang lebih tua samada mereka yang tinggal di rumah kebajikan warga emas atau tinggal di rumah bersama anakanak mereka. Kesunyian merupakan perasaan tidak dihargai, tidak diperlukan, kekurangan hubungan sosial dan pengunduran psikologi dalaman seseorang individu (Amran Hassan et al., 2013). Kesunyian merupakan masalah kesihatan mental yang utama di hadapi oleh warga emas ( Marziah Zakaria et al., 2013). Meskipun kesunyian ini turut dialami oleh golongan remaja dan dewasa namun, warga emas lebih cenderung untuk mengalami kesunyian kerana perubahan-perubahan hidup, sebagai 
contoh kematian pasangan, terputusnya hubungan sosial, kurangnya sahabat, persaraan, perpindahan anak-anak ke bandar, kemerosotan fungsi fizikal serta kognitif yang dialami (Lopatta, 1995; Berg, et al. 1981).

Jika dibandingkan dengan warga emas yang tinggal bersama keluarga, warga emas di rumah penjagaan lebih terdedah kepada risiko kesunyian kerana antara mereka ada yang disisihkan keluarga, sebatang kara, berasal dari kawasan gelandangan bahkan berjauhan daripada anak-anak tersayang dan keluarga. la lebih parah jika anak-anak itu mengabaikan mereka dengan cara tidak datang melawat dan langsung tidak menunjukkan keprihatinan. Malah, perkara yang lebih menyedihkan apabila terdapatnya budaya menghilangkan diri setelah meninggalkan ibu-bapa tua yang sakit di hospital, dan akhirnya pihak hospital perlu menghantar mereka ini ke pusat jagaan warga emas (Suraiyah Harun, 2017; Zaila Hussin \& Khadijah Alavi, 2016). Situasi-situasi pengabaian ini sudah pasti menimbulkan trauma dan kemurungan dalam kalangan ibu-bapa tua. Kadar prevalensi kesunyian, kegelisahan dan kemurungan dalam kalangan warga emas di rumah kebajikan dilaporkan masing-masing sebanyak 95.5\% (Nikmat et al., 2015), 38\% (Khairudin et al., 2011) dan 85.5\% (Nikmat et al., 2015).

Antara faktor yang menyumbang kepada peningkatan statistik kesunyian ini mungkin perubahan dalam kehidupan seperti kematian pasangan, kemerosotan dari sudut fizikal dan kognitif (Lopatta, 1995) disebabkan oleh interaksi sosial yang berkurang dengan orang lain (Brownie \& Horstmanshof, 2011), berpindah ke persekitaran yang tidak dikenali (Amzat \& Jayawardena, 2016) dan rutin yang tidak menarik dalam rumah kebajikan tersebut (Marziah Zakaria et al., 2013). Kajian Amran Hassan et al., (2013) menunjukan bahawa kesunyian berpunca daripada kelemahan unsur kerohanian atau spiritual. Selain itu, doktor dan penyedia perkhidmatan kesihatan dan pekerja sosial juga kurang terlatih dan tidak memiliki kemahiran untuk menangani isu kesunyian. Pesakit jarang ditanya tentang kesunyian. Oleh itu, terdapat keperluan untuk melatih pelajar perubatan, lapisan masyarakat dan profesional lain dalam mengenali kesunyian dan menguruskan masalah kesunyian secara kolektif. Mother Theresa menyatakan, "Kesunyian dan perasaan tidak diingini adalah kemiskinan yang paling teruk". Tanpa intervensi yang sesuai, masalah kesihatan mental ini 
39 Kesunyian Dalam Kalangan Warga Emas: Praktik Semasa Dan Solusi Dari Risalah An-Nur

boleh membawa kepada peningkatan kadar bunuh diri (Kiosses et al., 2014) dan memberikan implikasi yang besar kepada kualiti kehidupan warga emas. Oleh itu, adalah mustahak untuk mengenal pasti dan menggunakan intervensi yang sesuai untuk mengurangkan kesan masalah kesihatan mental ini.

\section{Kesunyian dari Perspektif Psikologi}

Kesunyian ditakrifkan sebagai kekurangan hubungan yang signifikan dengan orang lain atau ketidakupayaan untuk menjalinkan hubungan yang mencukupi (Brownie \& Horstmanshof, 2011). Beberapa teori telah digunakan untuk meneroka pelbagai jenis kesunyian. Walau bagaimanapun, terdapat empat teori utama iaitu teori eksistensial, psikodinamik, kognitif dan interaksionis yang menerangkan tentang kesunyian.

\section{Teori Eksistential}

Teori eksistensial adalah perspektif "Kristian" mengenai kesunyian. la menganggap kesunyian sebagai peluang positif yang ditambah dengan pengalaman cinta (love). Kesunyian dipandang sebagai aspek kehidupan yang diperlukan, dan pada saat-saat paling intim dalam kehidupan kita pada dasarnya adalah bersendiria.

Teori ini lebih memfokuskan pada pengalaman dan gambaran perasaan sunyi dan tidak menumpukan dari aspek tahap atau jenis kesunyian. la bersifat filosofikal yang memfokuskan kepada bagaimana individu menjalani kehidupan yang autentik. Menurut teori ini, individu akan menjalani kehidupan yang lebih autentik dan lebih menyedari persekitarannya dengan menyedari bahawa manusia dilahirkan sendirian, akan menjalani kehidupan sendirian dan akhirnya mati bersendirian. Antara mereka yang mempelopori teori ini adalah Clark Moustakas yang menghasilkan buku tentang kesunyian pada tahun 1961. Manakala, penyelidik lain dikenali sebagai Rubenstein dan Shaver (1982) pula menyusun sistem kata-kata yang dikaitkan dengan kesunyian.

\section{Teori Psikodinamik}

Teori psikodinamik menerangkan kesunyian terhasil dari keterikatan (attachment) dan dilema interpersonal, bayi dan kanak-kanak atau lebih dikenali sebagai hubungan yang terjalin antara ibu dan anak.. Hubungan 
keterikatan bayi dengan ibu. Melalui keterikatan ini, anak mengalami ikatan emosi dan cara berhubung dengan orang lain dan berasa sunyi apabila orang yang signifikan kepada mereka berada di luar penglihatan.

Sebilangan penyelidik menganggap kesunyian sebagai keadaan fikiran yang merupakan gejala neurosis yang berpunca dari kehidupan sebelumnya, yang menyukarkan warga emas untuk menjalin hubungan. Salah seorang sarjana yang membincangkan kesunyian sebagai fenomena patologi ialah Frieda Fromm-Reichmann Fromm Reichmann. Beliau adalah seorang psikoanalis terlatih yang berjaya menerangkan teori kesunyian hasil dari terapinya dengan pesakit skizofrenia. Beliau menggambarkan kesunyian sebagai fenomena yang diabaikan dan hampir tidak disebut dalam buku teks psikiatri (Fromm-Reichmann, 1967).

Batasan teori ini adalah bahawa ia hanya berfokus pada penjelasan patologi dan gagal mengambil kira dunia sosial warga emas, budaya mereka, dan kesan penuaan. (Donaldson \& Watson 1996, Victor et al. 2000).

\section{iii. Teori Kognitif}

Pendekatan kognitif didasarkan pada model perbezaan antara hubungan sosial yang diinginkan dan hubungan sosial yang sebenarnya. Kesunyian adalah tindak balas terhadap perbezaan antara tahap hubungan sosial yang diinginkan dan dicapai. Selain itu, proses kognitif terutama atribusi mempunyai pengaruh yang moderat terhadap pengalaman kesunyian (Peplau \& Perlman, 1982)

Perspektif defisit kognitif menyatakan bahawa kesunyian adalah defisit antara kuantiti dan/atau kualiti sebenar dan yang diingini dari penglibatan sosial (Peplau et al. 1982). Dalam kerangka ini, Teori Ketidakselarian Mental (Dykstra \& de Jong Gierveld 1994) menunjukkan bahawa kesunyian terhasil dari ketidakselarian antara kognitif, pengalaman dan harapan hubungan sosial. Teori kognitif memberi tumpuan kepada tindak balas dan pengalaman kesunyian dan ia juga menyedari sumbangan faktor sosial.Perspektif ini juga membezakan antara dua jenis kesunyian yang dikenali sebagai kesunyian emosi (kehilangan ikatan utama seperti 
41 Kesunyian Dalam Kalangan Warga Emas: Praktik Semasa Dan Solusi Dari Risalah An-Nur

pasangan) dari kesunyian sosial (rangkaian sosial yang semakin berkurangan).

\section{Teori Interaktionis}

Teori Interaktionis adalah teori keterikatan yang merujuk kepada sifat kesunyian emosi dan sosial. Dari perspektif interaksionis, individu menilai kesunyian emosi dan sosial mereka secara subjektif dari segi kualitinya tetapi juga dari segi kuantiti. Teori ini mengemukakan bahawa kesunyian disebabkan oleh kombinasi kekurangan keterikatan dan ketiadaan jaringan sosial yang mencukupi. Dianggap bahawa pengalaman kesunyian bergantung pada jenis keperibadian individu. Teori ini dikritik kerana keadaan yang digambarkan menyebabkan kesunyian tidak semestinya negatif dan oleh itu faktor lain juga mungkin terlibat dalam mewujudkan perasaan kesunyian. Di samping itu, teori ini dikritik kerana kesunyian sosial tidak semestinya menyebabkan kesunyian (Donaldson \& Watson 1996; Victor et al. 2000).

Pendekatan Interaksionis bersifat multidimensional, yang bermaksud bahawa terdapat pelbagai jenis kesunyian, termasuk kesunyian emosi dan sosial. Kesunyian disebabkan bukan dengan bersendirian tetapi dengan tanpa adanya hubungan atau rangkaian hubungan yang diperlukan. Dalam banyak keadaan, ini adalah tindak balas terhadap ketiadaan hubungan yang dekat dan sangat intim. Ini juga merupakan tindak balas terhadap ketiadaan penyediaan persahabatan yang bermakna, hubungan kolegial atau hubungan lain dengan komuniti yang koheren (Weiss, 1973). Berasaskan kepada reori-teori kesunyian yang telah dibincangkan, penulis mengenengahkan beberapa solusi kepada kesunyian dalam kalangan warga emas. Solusi ini merangkumi aspek kognitif, afektif dan psikososial.

\section{Solusi Kesunyian Warga Emas dari Perspektif Psikososial}

Circle of Friends adalah salah satu dari intervensi untuk mengatasi kesunyian yang diperkenalkan oleh para sarjana dan pengamal di Central Union untuk Kesejahteraan Umur di Universiti Helsinki pada awal 2000-an. Intervensi ini dibina berdasarkan model kumpulan pemulihan dengan tujuan pengurangan dan pencegahan kesunyian pada orang dewasa yang lebih tua. Circle of Friends ini dianggotai oleh kira-kira lapan orang dewasa yang lebih tua yang telah dikenal pasti kesunyian atau terpencil secara sosial. Mereka 
akan mengadakan pertemuan sebanyak 12 kali selama tiga bulan bersama dengan seorang fasilitator. Tujuannya adalah untuk membuat rakan baru, merasa kurang kesunyian, berkongsi perasaan kesunyian dengan orang lain, mengalami perkara yang bermakna bersama dan beralih ke kumpulan sokongan diri. Setiap sesi merangkumi tiga komponen: 1) Seni dan aktiviti inspirasi dengan perbincangan; 2 ) senaman berkumpulan dan perbincangan bertema kesihatan; dan 3) penulisan terapeutik dengan berkongsi dan merenung masalah yang berkaitan dengan kesunyian. Intervensi seperti ini sangat sesuai untuk populasi warga emas yang tinggal di komuniti, pusat harian dewasa dan kemudahan kediaman.

\section{Solusi Kesunyian Melalui Startegi Daya Tindak}

Perasaan kesunyian dapat dibantu melalui intervensi dengan menguatkan dalaman diri seseorang individu (Perlman dan Peplau, 1998). Kekuatan dalaman tersebut akan menentukan samaada perasaan itu perlu dibiarkan terus mengganggu kehidupan atau dikawal secara konstruktif. (Smith, 2009; Amran et al., 2012; Siti Marziah et al., 2012). Antara intervensi yang perkenalkan oleh Amran et al., (2012) adalah strategi daya tindak atau pun membuat aktiviti yang disukai oleh warga emas itu sendiri. Warga emas yang berada di rumah warga emas melakukan pelbagai kerja dan aktiviti seperti memasak, membaca buku, membaca akhbar, menonton TV, mendengar radio, menulis diari, mengumpul wang syiling, menari atau berjoget, membaca majalah, bercakap dengan sahabat, berjalan-jalan dalam rumah kebajikan dan menulis surat kepada seseorang yang signifikan dengan dirinya. Semua aktiviti ini boleh dianggap sebagai strategi daya tindak untuk warga emas bagi menghilangkan perasaan kesunyian tersebut (Amran hassan et al., 2012). Seperti warga emas di Jepun mereka mempunyai jangka hayat usia yang panjang berbanding negara tua seperti itali, Portugal dan Jerman sehinga di gelarkan sebagai "super aged nation" (Shukri Abdul Hamid \& Norliza Mukhtar, 2018). Antara salah satu faktor adalah kerana satu istilah yang dipegang oleh mereka iaitu "Ikigai". Ikigai ini bermaksud setiap hari mereka mempunyai tujuan untuk hidup. Oleh yang demikian, bagi mengelak dari berlakunya kesunyian dan bosan mengulangi aktiviti yang sama setiap hari, maka warga emas di sana mencipta sesuatu aktiviti yang membolehkan mereka bersemangat untuk bangun setiap hari. Antara aktiviti yang boleh dilakukan adalah berkebun, berniaga secara kecil-kecilan, bersenam dalam lingkungan kecil malah menikmati matahari naik bergerak di waktu pagi 
43 Kesunyian Dalam Kalangan Warga Emas: Praktik Semasa Dan Solusi Dari Risalah An-Nur

secara perlahan-perlahan juga sebagai asbab supaya mereka sabar dan bersemangat untuk bangun serta aktif di waktu pagi (Ken Mogi, 2017).

\section{Sokongan Linkungan oleh Kerajaan}

Kementerian Kesihatan Malaysia telah melaksanakan perkhidmatan kesihatan untuk warga emas iaitu mereka yang berumur 60 tahun dan ke atas pada tahun 1996 (dalam Rancangan Malaysia Ke-Tujuh) sebagai salah satu daripada program dalam Expanded Scope. Beberapa aktiviti telah diperkenalkan untuk menangani kesunyian warga emas seperti berikut:

\section{Program Khidmat bantu di Rumah}

Kewujudan sukarelawan Homehelp Jabatan Kebajikan Masyarakat (JKM) banyak membantu mengatasi kesunyian golongan warga emas. Program Khidmat Bantu di Rumah (Home Help Services) merupakan perkhidmatan sokongan sosial yang disediakan oleh sukarelawan kepada warga emas dan Orang Kurang Upaya (OKU) di rumah. Program ini juga bertujuan menyemarakkan perkembangan kesukarelawan (volunteerism) yang lebih tersusun dan berkesan dalam masyarakat

\section{Pusat Aktiviti Warga Emas}

Warga Emas boleh terlibat dengan aktiviti di Pusat Aktiviti Warga Emas. Pusat Aktiviti Warga Emas (PAWE) ialah tempat bagi warga emas menjalankan aktiviti harian dalam komuniti. la merupakan satu perkhidmatan bercorak pendampingan sosial (reaching out) dan pembangunan (developmental) kepada warga emas melibatkan kerjasama strategik antara Kementerian Pembangunan Wanita Keluarga dan Masyarakat (KPWKM) dengan agensi kerajaan yang lain serta pertubuhan bukan kerajaan (NGO).

\section{Kelab Warga Emas}

Kelab Warga Emas merupakan satu inisiatif untuk menggalakkan penglibatan komuniti dan badan bukan kerajaan dalam penjagaan warga emas. Setakat 2017, terdapat 233 buah Kelab Warga Emas yang bernaung di bawah Klinik Kesihatan induk di seluruh Malaysia. Walaupun terdapat program-program yang dijalankan oleh kerajaan Malaysia dan juga di negara 
Noornajihan Jaafar, Rezki Perdani Sawai, Shah Rizul Izyan, Celal Akar 44

lain untuk menangani kesunyian dalam kalangan warga emas, namun, intervensi tersebut kurang menekankan kepada dimensi kerohanian.

\section{Kepentingan Intervensi Berbentuk Kerohanian}

Rasa keterhubungan (sense of connectedness) berperanan dalam mengurangkan kesunyian, kegelisahan dan kemurungan. Rasa keterhubungan ini adalah komponen penting dalam kesihatan mental warga emas. Ini disokong oleh Lundman et al. (2010) yang mendakwa keterhubungan adalah salah satu sumber dalaman untuk meningkatkan kesihatan dalam kalangan warga emas berusia 85 tahun ke atas. Begitu juga dengan Haslam et al. (2013) berpendapat bahawa rasa keterhubungan adalah komponen utama untuk meningkatkan kesihatan. Contohnya, kurangnya perasaan keterhubungan berkaitan dengan kesunyian dalam kalangan 40 warga emas yang berada di rumah (Han \& Richardson, 2010). Melalui aktiviti kerohanian seperti berdoa dan meditasi, individu merasakan hubungan dengan Tuhan dan orang lain di sekelilingnya (Byrne \& MacKinlay, 2012).

Keperluan program intervensi kerohanian perlu diberi perhatian bagi meningkatkan kesejahteraan warga emas. Bagi warga emas yang beragama Islam, keadaan jiwa yang tenang adalah sangat penting pada setiap masa terutama sekali ketika di penghujung usia. Kajian awal mendapati, kurangnya kajian empirik yang dijalankan bagi mengkaji hubungan antara aspek psikologi dengan aspek rohani warga emas (Tengku Aizan, 2015). Namun, aspek psikospiritual ini tidak boleh diabaikan begitu sahaja kerana terdapat banyak isu yang berkait rapat dengan psikologi warga emas seperti kemurungan, kesunyian, masalah kesihatan mental dan sebagainya.

Rasa keterhubungan berperanan dalam mengurangkan kesunyian, kegelisahan dan kemurungan. Rasa keterhubungan ini adalah komponen penting dalam kesihatan mental warga emas. Ini disokong oleh Lundman et al. (2010) yang mendakwa keterhubungan adalah salah satu sumber dalaman untuk meningkatkan kesihatan dalam kalangan warga emas berusia 85 tahun ke atas. Begitu juga dengan Haslam et al. (2013) berpendapat bahawa rasa keterhubungan adalah komponen utama untuk meningkatkan kesihatan. Contohnya, kurangnya perasaan keterhubungan berkaitan dengan kesunyian dalam kalangan 40 warga emas yang berada di rumah (Han \& Richardson, 2010). Melalui aktiviti kerohanian seperti berdoa 
45 Kesunyian Dalam Kalangan Warga Emas: Praktik Semasa Dan Solusi Dari Risalah An-Nur

dan meditasi, individu merasakan hubungan dengan Tuhan dan orang lain di sekelilingnya (Byrne \& MacKinlay, 2012). Oleh demikian, penulis mengenengahkan solusi kesunyiaan dalam kalangan warga emas dari perspektif Risalah An-Nur khususnya bagi yang beragama Islam sebagai salah satu intervebsi berbentuk kerohanian.

\section{Solusi Kesunyian Warga Emas dari Perspektif Risalah An-Nur}

Usia tua merupakan suatu usia yang dibimbangi dan ditakuti oleh manusia. Kemerosotan yang terjadi dari sudut fizikal, kognitif dan juga psikologi sering menjadikan warga emas merasa murung, sedih dan kesunyian. Namun begitu, Bediuzzaman Said Nursi membawa satu lensa pemikiran yang baru buat warga emas dalam mengharungi usia tua mereka dengan keadaan yang tenang dan bahagia. Penawar dan harapan yang ditonjolkan oleh beliau bertujuan supaya warga emas menjadikan al-Quran sebagai syifa dan kekuatan untuk bersandar ketika di hujung usia.

Bediuzzaman Said Nursi telah berkongsi dengan para pembaca tentang pengalaman beliau terhadap refleksi perjalanan kehidupannya sebagai seorang warga emas, walaupun ketika itu beliau baru sahaja berumur awal 40-an. Perkongsian ini ditulis dalam kitab Kilauan Kedua puluh enam yang merupakan anatara koleksi kitab beliau yang dikenali sebagai Risalah AnNur. Dalam penulisan tersebut, beliau telah menyebut 26 harapan yang berpaksikan lensa keimanan kepada Allah sebagai penawar kepada segala bentuk masalah psikologi yang dialami oleh seseorang warga emas. Setiap harapan memberikan penawar bagi masalah psikologi yang dialami oleh warga emas dalam bentuk lensa keimanan terhadap sesuatu situasi perjalanan kehidupan yang direnungkan. Dalam penulisan ini ditengahkan tiga solusi cara fikir yang dikenali sebagai harapan kepada penawar kesunyiaan. laitu harapan pertama, keenam dan kelapan. Hasil kajian menunjukkan bahawa dengan tiga harapan yang diketengahkan oleh Bediuzzaman Said Nursi ini mampu meningkatkan keimanan dan menjadikan warga emas berada dalam satu keadaan tidak merasai kesunyian dalam kehidupan ini.

\section{Harapan Pertama}

Keimanan kepada Allah merupakan asas kepada segala harapan bagi warga emas. Pandangan iman akan mengubah lensa seseoarang warga emas dalam 
menanggapi emosi yang sedang dialami seperti rasa lemah tidak berdaya, sunyi, takut dengan perpisahan, kekecewaan, rasa bersalah, penyesalan dan lain-lain emosi lagi. Memamandangkan Allah wujud dan semua ciptaan ini milikNya maka tiada kesunyian jika Dia dikenali.

\section{Harapan Keenam:}

Segelintir yang kurang bernasib baik, ditinggalkan anak-anak di rumah orang-warga emas. Dalam hal ini, warga emas yang anak-anaknya sudah besar dan mempunyai keluarga dan kerjaya sendiri, sudah tentu mereka berasa kesunyian. Namun, dengan keyakinan bahawa Allah itu sentiasa ada bersamanya. Allah menghantarkan malaikat hafazah untuk menjaga mereka. Allah SWT menciptakan segala di langit dan di bumi untuk untuk kegunaan manusia. Apabila seseorang warga emas meyakini akan hal ini, secara hakikatnya mereka tidak merasa sunyi kerana seluruh alam ini yang terdiri daripada binatang, tumbuh-tumbuhan, angin, awan, dan lain-lain merupakan penemannya. Bediuzzaman Said Nursi menyatakan:

"Ya, wahai warga tua lelaki dan perempuan! Memandangkan al-Khaliq kita yang ar-Rahim ada, maka tidak akan ada keterasingan untuk kita. Memandangkan Dia ada maka semuanya ada untuk kita. Memandangkan Dia ada, maka para malaikat-Nya juga ada. Oleh itu, (maknanya) dunia ini tidak kosong. Gunung-ganang yang sepi, padang-padang pasir yang tandus adalah penuh dengan hamba-hamba Al-Haqq Subhanahu wa Ta'ala. Selain daripada hamba-hamba-Nya yang berakal, dengan cahaya-Nya, dengan perhitungan-Nya, batu dan pohon-Nya juga adalah ibarat teman-teman yang mesra. Makhluk-makhluk itu boleh berbicara dengan kita melalui lisan al-hal mereka dan menghiburkan kita.".

Keimanan kepada Allah merupakan penawar kepada rasa keterasingan dan kesunyiaan semasa usia emas ini. Maka, perlulah setiap individu mempersiapkan diri dengan keimanan kepada Allah dengan sebenar-benar iman agak kelak apabila masuk ke usia emas, hidup tidak terasa sunyi dan terasing. Apabiala Allah ada di dalam hati maka segalanya ada bagi kita.

\section{Harapan Kelapan:}

Selain dengan kesedihan untuk berpisah dengan kehidupan dunia, fenomena hari ini dengan anak-anak sibuk dengan kerjaya masing-masing, ada dalam kalangan warga emas yang merasa kesunyian walaupun tinggal 


\section{Kesunyian Dalam Kalangan Warga Emas: Praktik Semasa Dan Solusi Dari Risalah An-Nur}

serumah bersama anak-anak. Harapan kelapan ini memberi penawar bagi kesunyian tersebut.

Ketika Said Nursi berada di Istanbul semasa tahun-tahun akhir pemerintahan Uthmaniyah beliau merasai kesunyian kerana tanda ketuaan mula mewarnai rambut di kepalanya, kehuru-haraan perang dunia dan ketidaktentuan penawananya. Bermula daripada khalifah, syaikhul Islam, ketua panglima sehingga kepada murid-murid madrasah memperlihatkan suatu perhatian dan tolehan yang baik yang amat melebihi kemampuanya. Maka keadaan rohani yang diberikan oleh kemabukan masa muda dan keadaan itu telah menebalkan lena itu hingga ke suatu tahap seolah-olah belia telah melihat dunia sebagai kekal dan diriya sendiri juga telah berpaut pada dunia dalam suatu keadaan yang menghairankan bagaikan tidak akan mati. Justeru pada masa itu, dalam bulan Ramadhan, Said Nursi telah pergi ke Masjid mulia Beyazid di Istanbul untuk mendengar para huffaz yang ikhlas (Nursi, 2015).

Beliau dapati, melalui khitab samawinya yang tinggi, al-Quran mu'jiz alBayan mengumumkan firman [كُلُّ نَفْسِ ذَائقَقَة الْمَوْتِ] yang memberi khabar kefanaan manusia dan kematian makhluk bernyawa dalam bentuk yang tegas menerusi lidah para huffaz. Justeru, beliau nampak bahawa masa muda yang amat dia percayai dan terpesona dengan kelazatannya mengucapkan selamat tinggal kepadanya. Kehidupan duniawi yang amat dia kasihi mula malap. Dunia yang amat berkait denganya dan seolah-olah dia terlalu mencintainya mengucapkan "semoga bertuah!" lalu memperingatkan bahawa dia akan meninggalkan rumah pertamuan ini. Dirinya juga mengucapkan "semoga dilindungi Allah" bersedia untuk pergi.

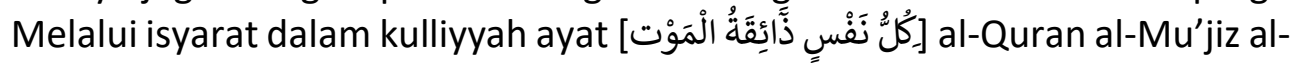
Bayan, terbukalah makna pada hati bahawa bangsa manusia adalah satu jiwa dan ia akan mati untuk dibangkitkan semula. Bebola bumi juga adalah satu jiwa. la juga akan mati untu memasuki suatu bentuk keabadian. Dunia juga adalah satu jiwa dan ia juga akan mati untuk menjadi akhirat.

Sekali lagi, beliau mula mendengar bacaan para Huffaz di Masjid Beyazid untuk mendengar ajaran samawi al-Quran. Bediuzzaman Sid Nursi berkata:

"Waktu itu aku telah mendengar khabar-khabar gembira melalui firmanfirman qudsi yang dari jenis ayat [وََ بَشِّّ الَّْنينَ آمَنُوا] hingga akhir. Bahkan aku telah mencari hiburan, harapan dan nur dalam noktah-noktah yang telah aku ambil daripada kedahsyatan, kesunyian dan keputuas asaan bukannya 
mencari hiburan dari luar menerusi limpahan yang aku dapatkan daripada al-Quran. Seratus ribu syukur kepada Allah Subhanahu wa Taala kerana aku telah menemui penawar di dalam penyakit itu sendiri, menemui cahaya di dalam kegelapan itu sendiri dan menemui hiburan di dalam kesunyian itu sendiri. Aku telah memandang kepada wajah kematian yang disangkakan sebagai yang paling menakutkan semua orang dan yang paling menyeramkan dan melalui nur al-Quran aku nampak bahawa cakaran kematian pada zahirnya adalah gelap, hitam dan jelik, namun bagi orang mukmin, wajah aslinya adalah bercahaya dan indah". Beliau menyambung lagi:

\begin{abstract}
"Aku melafazkan seratus ribu syukur kepada al-Khaliq Dzul Jalal yang menjadikan dunia ini dalam bentuk ini. Aku telah faham bahawa walaupun rasa cinta telah diberikan kepada bangsa manusia terhadap wajah indah sebenar dunia yang memandang kepada akhirat dan nama-nama llahi, namun oleh sebab manusia telah menyalahgunakannya dengan menghabiskan rasa cinta itu terhadap wajah dunia yang fana, hodoh, bermudarat dan melalaikan, maka mereka menjadi penzahir makna hadis

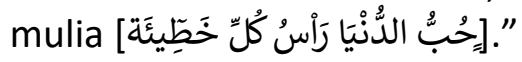

Beliau meneruskan kata-katanya:

"Justeru, wahai orang-warga emas lelaki dan wanita! Aku telah nampak hakikat ini melalui nur al-Quran al-Hakim, melalui peringatan masa tua dan kerana keimanan juga telah membuka mataku dan aku telah mengisbatkannya dalam banyak risalah dengan burhan-burhan yang qat'i (bukti-bukti yang nyata). Aku telah nampak suatu hiburan yang hakiki, suatu harapan yang kuat dan suatu cahaya yang terang untuk diriku. Aku berasa gembira dengan masa tuaku dan aku senang hati dengan perginya masa muda. Maka kalian juga janganlah menangis dan hendaklah kalian bersyukur. Memandangkan ada keimanan dan beginilah hakikat, biarlah mereka yang lalai menangis dan mereka yang sesat menangis." (Nursi, 2015).

\title{
Penutup
}


49 Kesunyian Dalam Kalangan Warga Emas: Praktik Semasa Dan Solusi Dari Risalah An-Nur

Tidak semua warga emas mengalami kesunyian dengan cara yang sama atau pada tahap yang sama dan oleh itu terdapat keperluan mendesak untuk menyesuaikan bentuk intervensi yang memenuhi kehendak individu. Adalah disarankan agar penyelidikan masa depan membezakan pelbagai kumpulan orang dewasa yang lebih tua yang mengetahui intervensi apa yang berfungsi untuk kumpulan kecil populasi ini; konteks di mana intervensi ini berfungsi; dan mekanisme di mana mereka beroperasi dalam konteks yang diberikan. Maklumat ini akan sangat berharga dalam perancangan dan pelaksanaan program untuk mengurangkan kesunyian, dan meningkatkan kesejahteraan warga emas terutamanya mereka yang beragama Islam. Warga emas perlu dibantu untuk menangani kesunyian supaya mereka mempunyai kualiti jiwa yang lebih baik, dapat melalui proses penuaan yang aktif dan sihat. Pihak keluarga dan masyarakat secara keseluruhannya berperanan untuk membantu warga emas dalam menangani isu kesunyian ini, walaupun mereka telah membuat keputusan untuk menghantar ibu-bapa ke institusi penjagaan.

\section{PENGHARGAAN}

Kajian ini adalah sebahagian penyelidikan di Institut Sains Islam, Universiti Sains Islam Malaysia dengan kerjasama Yayasan Hayrat, Turki.

\section{RUJUKAN}

Ahmad Shukri Abdul Hamid, \& Norliza Mokhtar. (2018). Malaysia Menuju Negara Tua: Apakah Yang Boleh Dipelajari Daripada Pengalaman Negara Jepun ? Human Sustainability Procedia, November, 406-419.

Ahmad E Kadi (1985), Health and Healing In The Quran: American Journal of Islamic Social Science, Vol. 2, No. 2, p. 294-295.

Akar, C., \& Zainal Abidin, S. (2019). Gaya Hıdup Nabawı: Prınsıp-Prınsıp Nabawi Yang Diamalkan Imam Said Nursi Dalam Pemakanan. 'Abqari Journal. 17, 1 (Feb. 2019), 57-64.

Amran Hassan, Noriah Mohamed dan Zubaidah Raso (2013). Perasaan 'Loneliness'@ Kesunyian dan Strategi Daya Tindak. 2, 89-103. 
Noornajihan Jaafar, Rezki Perdani Sawai, Shah Rizul Izyan, Celal Akar 50

Amzat, I. H., \& Jayawardena, P. (2016). Emotional Loneliness and Coping Strategies: A Reference to Older Malaysians at Nursing Homes. Journal of Population Ageing, 9(3), 227-247. https://doi.org/10.1007/s12062015-9135.

Badiuzaman Said Nursi. (2015). Al-Lamaat. Tahkik Ihsan Qasih As-Sahlihi. Cet. 6. Kaherah: Sozler.

Berg-Weger, M., Morley, J.E. (2020). Loneliness in Old Age: An Unaddressed Health Problem. Journal Nutrition Health Aging. 24, 243-245. https://doi.org/10.1007/s12603-020-1323-6.

Berg, S., Mellstrom, D., Persson, G., \& Svanborg, A. (1981). Loneliness in Swedish aged. Journal of Gerontology, 36 (3), 342-349.

Boulton-Lewis, G. M. (2010). Education and learning for the elderly: Why, how, what. Educational Gerontology, 36(3), 213-228. https://doi.org/10.1080/03601270903182877.

Byrne, L., \& Mackinlay, E. (2012). Seeking Meaning: Making Art and the Experience of Spirituality in Dementia Care. Journal of Religion, Spirituality \& Aging, 24(1-2), 105-119. doi:10.1080/15528030.2012.633416

Brosens, D., De Donder, L., Vanwing, T., Dury, S., \& Verté, D. (2014). Lifelong Learning Programs in Prison: Influence of Social Networks on Participation. Procedia - Social and Behavioral Sciences, 116, 518-523. https://doi.org/10.1016/j.sbspro.2014.01.251

Brownie, S., \& Horstmanshof, L. (2011). The Management of Loneliness in Aged Care Residents: An Important Therapeutic Target for Gerontological Nursing. Geriatric Nursing, 32(5), 318-325. https://doi.org/10.1016/j.gerinurse.2011.05.003.

Cosan, D. (2014). An Evaluation of Loneliness. April, 103-110. https://doi.org/10.15405/epsbs.2014.05.13. 
51 Kesunyian Dalam Kalangan Warga Emas: Praktik Semasa Dan Solusi Dari Risalah An-Nur

Donaldson, J., \& Watson, R. (1996). Donaldson - Loneliness in Elderly. In Journal of advanced nursing (Vol. 24, pp. 952-959).

Doufesh, H., Ibrahim, F., Ismail, N. A., \& Ahmad, W. A. W. (2016). Adaptive Neuro-Fuzzy Inference System for Predicting Alpha Band Power of Eeg During Muslim Prayer (Salat). Biomedical Engineering-Applications Basis Communications, 28(6), 1-9. https://doi.org/10.4015/S1016237216500435

De Jong Gierveld, J., Van Tilburg, T. G., \& Dykstra, P. A. (in press). New Ways of Theorizing and Conducting Research in the Field of Loneliness and Social Isolation. In A. L. Vangelisti \& D. Perlman (Eds.), Cambridge Handbook of Personal Relationships, 2nd revised edition. Cambridge, New York: Cambridge University Press.

Green, H. (1967). "In Praise of My Doctor" - Frieda Fromm-Reichmann. Contemporary Psychoanalysis, 4(1), 73-77. https://doi.org/10.1080/00107530.1967.10745130.

Haslam, C., Haslam, S. A., Ysseldyk, R., McCloskey, L., Pfisterer, K., \& Brown, S.G. (2013). Social identification moderates cognitive health and wellbeing following story- and song-based reminiscence. Aging \& Mental Health, 18(4), 425-434. doi:10.1080/13607863.2013.845871.

Husin, S. Z., \& Alavi, K. (2016). Kerja Sosial Di Hospital: Meneroka Pengabaian. Journal of Social Sciences and Humanities, 11(2), 462484.

Fakoya, O.A., McCorry, N.K. \& Donnelly, M. (2020). Loneliness and social isolation interventions for older adults: a scoping review of reviews. BMC Public Health. 20, 129. https://doi.org/10.1186/s12889-0208251-6.

Han, J., \& Richardson, V.E. (2010). The Relationship Between Depression and Loneliness Among Homebound Older Persons: Does Spirituality 
Noornajihan Jaafar, Rezki Perdani Sawai, Shah Rizul Izyan, Celal Akar 52

Moderate This Relationship? Journal of Religion \& Spirituality in Social

Work: Social Thought, 29(3), 218-236.

doi:10.1080/15426432.2010.495610

Ken Mogi (2017) The Litte Book Of Ikigai Live A Happy And Long Life The Japanese Way. An Hachette UK company.

Khairudin R, Nasir R, Zainah AZ, Fatimah Y, Fatimah O. (2011). Depression, Anxiety and Locus of Control among Elderly with Dementia. Pertanika Journal of Social Sciences \& Humanities. 19:27-31.

Kiosses, D. N., \& Alexopoulos, G. S. (2014). Problem-Solving Therapy in the Elderly. Current Treatment Options in Psychiatry, 1(1), 15-26. https://doi.org/10.1007/s40501-013-0003-0.

Lundman, B., Aléx, L., Jonsén, E., Norberg, A., Nygren, B., Santamäki Fischer, R., \& Strandberg, G. (2010). Inner strength-A theoretical analysis of salutogenic concepts. International Journal of Nursing Studies, 47(2), 251-260. https://doi.org/10.1016/j.ijnurstu.2009.05.020.

Lopata, H.Z. (1995). Feminist perspective in Social Gerontology. Handbook of Aging and the

Family. Westport, C.T: Greenwood.

Mariam Abd majid (2018). Program Pendidikan Warga Emas Di Institusi ProgramPendidikan Warga Emas Di Institusi Pondok Al-Jenderami. Jurnal Hal Ehwal Islam Dan Warisan Selangor, 1(1).

Moustakas, C.E. (1961). Loneliness. Englewood Cliffs, N.J.: Prentice Hall.

Nikmat, A.W., Hashim, N.A., Omar, S.A., \& Razali, S. (2015). Depression And Loneliness/Social Isolation Among Patients With Cognitive Impairment In Nursing Home. ASEAN Journal of Psychiatry, 16(2), 222231. 
53 Kesunyian Dalam Kalangan Warga Emas: Praktik Semasa Dan Solusi Dari Risalah An-Nur

Peplau, L. A., \& Perlman, D. (1982b). Theoretical Approaches to Loneliness. In L. A. Peplau \& D. Perlman (Eds.), Loneliness: A sourcebook of current theory, research and therapy (pp. 123-134). New York: Wiley.

Rubenstein, C., \& Shaver, P. (1980). Loneliness in two northeastern cities. In J. Hartog, J. R. Audy, \& Y. A. Cohen (Eds.), The anatomy of loneliness. New York: International University Press. Rubenstein,

Said Nursi, Bediuzzaman. (2015), Lem'alar Mecmuası. Isparta: Hayrat Neşriyat.

Sharifah Munirah Syed Elias. (2017). Spiritual reminiscence therapy for older people with loneliness, anxiety and depression living in a residential aged care facility, Malaysia: The effectiveness and older people's experiences. Unpublished doctoral thesis. Australia: University of Queensland.

Singh, B. \& Kiran, U.V. (2013). Loneliness among elderly women. International Journal of Humanities and Social Science Invention. ISSN (Online): 2319 - 7722, ISSN (Print): 2319 - 7714.

Siti Marziah Zakaria, Khadijah Alavi \& Nasrudin Subhi. (2013). Risiko kesunyian dalam kalangan warga tua di rumah Seri Kenangan. Journal of Psychology \& Human Development. 1: 49-56.

Suraiyah Harun. 31 Januari 2017 "Warga emas Terabai" http://www.myhealth.gov.my/warga-emas-terabai/ (diakses pada 2 Mac 2019).

Smith M (2009) Overcoming loneliness. from: www.mpclife.com/.../mukileto/images/ Available oreang\%20loneliness.pdf

Tamat, A., \& Vellymalay, S. K. N. (2019). Warga Emas Dan Pilihan Penempatan Di Pusat Jagaan Harian. E-Bangi, 16(4), 1-22. 
Noornajihan Jaafar, Rezki Perdani Sawai, Shah Rizul Izyan, Celal Akar 54

Tengku Aizan Tengku Abdul Hamid (2015). Population Ageing in Malaysia: A Mosaic of Issues, Challenges \& Prospects. Didapatkan dari http://psasir.upm.edu.my/id/eprint/41616/2/POPULATION.pdf

Victor, C., Scambler, S., \& Bowling, A. (2000). Being alone in later life: loneliness, social isolation and living alone. ( Reviews in Clinical Gerontology 2000 10; 407-417)

Weiss, R. S., Bowlby, J., \& Parkes, C. M. (1973). Affectional Bonds: Their Nature and Origin. Loneliness: The experience of emotional and social isolation (38-52). Cambridge, MA: MIT Press.

Weiss, R. S., Bowlby, J., \& Parkes, C. M. (1973). The Study of Loneliness. Loneliness: The experience of emotional and social isolation (7-30). Cambridge, MA: MIT Press.

laman web Jabatan Kebajikan Masyarakat :

https://www.jkm.gov.my/jkm/index.php?r=portal/left\&id=WjFUdFBURTV0 Zis0N0NxYm05Qk9XQT09 di akses pada 27 april 2020

https://www.kpwkm.gov.my/kpwkm/uploads/files/Dokumen/Dasar/Dasar \%20Warga\%20Emas_2011.pdf 